Monika Dobosz

ORCID: 0000-0001-7659-1562

Jacek Kozak

ORCID: 0000-0003-1001-8151

Natalia Kolecka

ORCID: 0000-0001-6143-0870

\title{
INTEGRATING CONTEMPORARY SPATIAL FOREST COVER DATA IN THE POLISH CARPATHIANS: DOES ABUNDANCE OF DATA INCREASE KNOWLEDGE OR UNCERTAINTY?
}

\author{
Department of GIS, Cartography and Remote Sensing, Institute of Geography and Spatial Management, Jagiellonian University
}

Keywords: forest mapping, forest definition, forest cover, data integration, uncertainty, Carpathians

\begin{abstract}
Though the State Forests in Poland maintain an accurate spatial database covering roughly $80 \%$ of the forest area in Poland, the remaining $20 \%$ of forests, mostly private, are not mapped with similar accuracy. Several national mapping projects have been carried out in Poland recently, yet it is not trivial to integrate their results in the context of forest cover estimation, due to inconsistencies of incorporated forest definitions. For instance, some datasets exclude areas which are legally forest, but temporarily devoid of trees due to damage by wind or pests. Moreover, the unknown extent of secondary forest succession on abandoned agricultural land introduces much uncertainty in assessing the actual forest area. Our work proposes therefore a semi-automatic algorithm that integrates spatial data on contemporary forest cover from various sources, and eliminates their mutual inconsistencies. The study was conducted in the Polish Carpathians, where, due to a high share of private forests, reliable forest cover estimates are particularly difficult. The approach combines forest cover information from the national topographic data, both past (1970s) and current (2010s) and from the State Forests spatial databases. Contrary to the current national topographic data, the produced map presents forests in coherence with the Polish forest definition and is comparable to the earlier topographic maps. Our results suggest that various databases underestimate forest cover in the Polish Carpathians, and that the expert knowledge-based fusion of the datasets may provide complete and reliable information on the actual current forest cover in the region.
\end{abstract}

\section{INTEGRACJA WSPÓECZESNYCH DANYCH PRZESTRZENNYCH O LASACH W KARPATACH POLSKICH: CZY OBFITOŚĆ DANYCH ZWIĘKSZA WIEDZĘ CZY NIEPEWNOŚĆ?}

Słowa kluczowe: kartowanie lasów, definicja lasu, powierzchnia lasów, integracja danych, niepewność, Karpaty

\begin{abstract}
Abstrakt
Lasy Państwowe w Polsce utrzymują dokładną przestrzenną bazę danych obejmującą około 80\% powierzchni lasów w Polsce. Jednakże pozostałe 20\% lasów, głównie prywatnych, jest kartowane ze znacznie mniejszą dokładnością. W ostatnich latach w Polsce zrealizowane zostały różne projekty pozyskiwania danych przestrzennych o zasięgu krajowym, jednakże integracja ich wyników w celu uzyskania wartości lesistości nie jest łatwa, z uwagi na niespójności w przyjętych definicjach lasu. Na przykład, w niektórych zbiorach danych nie uwzględnia się obszarów, które prawnie są lasami, natomiast chwilowo są wylesione wskutek uszkodzeń drzewostanów przez wiatry lub szkodniki. Niepewność w szacunkach powierzchni lasów wprowadza też sukcesja leśna na porzuconych gruntach rolnych, której zasięg przestrzenny jest na ogół nieznany. W naszej pracy zaproponowaliśmy więc półautomatyczny algorytm integrujący dane przestrzenne o lasach pochodzące z różnych współczesnych źródeł, który
\end{abstract}


eliminuje występujące w tych danych niespójności. Badania przeprowadzone zostały w Karpatach polskich, gdzie, z uwagi na duży odsetek lasów prywatnych, rzetelne oszacowanie powierzchni lasów jest szczególnie trudne. Zastosowane podejście łączy informacje o rozmieszczeniu lasów z polskich danych topograficznych, zarówno historycznych (lata 70. XX wieku), jak i współczesnych, oraz z przestrzennych baz danych Lasów Państwowych. Inaczej niż współczesne dane topograficzne, opracowana mapa przedstawia lasy zgodnie z polską definicją prawną i jest w ten sposób porównywalna do wcześniejszych opracowań topograficznych. Nasze wyniki wskazują, że różne współczesne bazy danych zaniżają lesistość Karpat polskich, natomiast fuzja różnych zbiorów danych poparta wiedzą ekspercką pozwala na uzyskanie kompletnej i rzetelnej informacji o współczesnym rozmieszczeniu lasów w tym regionie.

\section{INTRODUCTION}

Accurate assessments of forested area and its spatial extent at a national scale are important as they allow to identify the on-going land cover transitions (Keenan et al., 2015), provide critical variable to estimate national carbon balance (Andersson et al., 2009), and bring source data for spatially explicit modeling of past and future forest cover trajectories (Kaim et al., 2016; Kunz, 2006; Price et al., 2014). Mapping forests is also crucial to understand the global climate change and may have direct implications in economy and environmental policy (Bonan, 2008). A number of global and regional maps of forest extent are available, but when compared spatially, there are large areas of disagreement (Schepaschenko et al., 2015). In many cases it is difficult to reliably assess forest cover and its changes as they are susceptible to many interrelated drivers, both natural and anthropogenic ones, and occur over a range of spatial and temporal scales. In the long run, that complexity involves also altering and inconsistent forest definitions and a variety of policy actors involved in monitoring and reporting forest cover at various spatial scales. Another difficulty is that the variety of data types and acquisition methods have increased over time. For instance, European National Forest Inventories (NFIs) traditionally focused on economically oriented forest attributes (i.e. wood production), but nowadays are involved also in carbon pool estimation or biodiversity assessment. These shifting demands imply new requirements and applications of NFIs database and forest data collection methods (Gschwantner et al., 2009).

In Poland, the State Forests (Lasy Państwowe, SF) is responsible for the forest information system in Poland, but its operations and reporting are limited to the land owned by SF, that is $77.1 \%$ of the Polish forests (Raport..., 2015). SF maps their forests by means of land surveys, frequently combined with remote sensing methods, such as Light Detection and Ranging (Li-
DAR) and optical aerial or satellite imagery. As almost a quarter of the Polish forests (mostly private) remain at present outside the SF survey system, the annual forest cover assessments in Poland, published in statistical yearbooks by the Central Statistical Office of Poland (Główny Urząd Statystyczny, GUS) combine SF information with cadastral data. Statements of the official representatives of SF, similarly as the latest research (Hościło et al., 2016) suggest that the present forest cover in Poland may be underestimated and new approaches to forest cover mapping in Poland are needed. Hościło et al. (2016) found out that the actual forest cover in Poland is significantly higher than the $29.4 \%$ provided by GUS official statistics. The authors reported the country forest cover of $32 \%$ and $33.5 \%$ with respect to the national forest definition and to the Kyoto Protocol forest definition, respectively. The main reason for the forest area underestimation is that abandoned agricultural land with secondary forest succession is still classified as agricultural land in the cadastral system, regardless the stage of forest succession (Szostak et al., 2014; Jabłoński, 2015). Though land owners should report changes in land use of any parcel, the practice has shown that this happens rarely if agricultural activities have ceased and land has been abandoned. This significant uncertainty refers therefore only to areas outside SF, for which cadastral data are the primary source of land cover information. Critical knowledge gaps may thus occur in areas with low proportion of forests administered by SF, for instance in the Polish Carpathians, where they constitute only about $50 \%$ of the total forest area, and where extensive agricultural land abandonment and secondary forest succession are currently observed (Kolecka et al., 2017).

Our main goal was to investigate if combination of diverse available spatial data sources reduces the uncertainty and allows to produce more accurate forest maps than individual forest data layers (Lesiv et al., 2016). Specifically, we intended to produce a map showing contemporary forest cover in the Polish Carpathians at 
high spatial resolution of approximately $10 \mathrm{~m}$ to allow consistent long-term spatially explicit reconstructions of forest cover trajectories based on forest cover data extracted from historical topographic maps (1860s-1970s) for the same region (Kaim et al., 2014, 2016; Ostafin et al., 2017). To reach our goals, we devised an algorithm to modify and integrate various available data layers. In the end, we assessed pitfalls of inconsistent forest definitions and mapping methods used to create forest cover data at the national scale, relating them also to forest cover change phenomena present in the studied area. Finally, this work was meant to provide answers to a more generic question: to what extent does the abundance of spatial data increase our knowledge on certain phenomena, and to what extent does it contribute to increased uncertainty?

\section{FOREST DEFINITIONS AND THEIR CONSEQUENCES FOR MAPPING}

Various forest definitions have been in use over the last decades (Chazdon et al., 2016) to improve accuracy of forest resources assessment both at the national and regional level. Forest can be described as (1) an administrative or legal unit, (2) land cover, (3) land use, and (4) land capability (Lund, 2014). Various countries emphasize various aspects of forest definition - for instance, Lund (1999) identified over 130 different definitions of forest and forest land, including 8 definitions based on administrative unit, 66 on land cover and 59 on land use. Therefore, forest area estimates vary according to the accepted definition and data used (Lund, 2014).

The fundamental problem is to use forest definition appropriate to the scale and analyzed phenomena (Sasaki, Putz, 2009). From the point of view of land changes and their reconstructions, two out of four aspects of forest definition are of particular importance: land cover and land use. Land cover refers to direct observations of the land surface, while land use is a socio-economic interpretation of the phenomena occurring on the land surface (Fisher et al., 2005). Land use and land cover terms are not interchangeable and confusion between them leads to many problems in data integration (Comber, 2008), especially as they have complex many-to-many relations (Fisher et al., 2005).

According to Food and Agriculture Organization of the United Nations (FAO) 'forest' is a land of at least 0.5 ha covered by trees higher than $5 \mathrm{~m}$ and with a can- opy cover of more than $10 \%$, or by trees able to reach these thresholds, and predominantly under forest land use, not including land that is mainly under agricultural or urban land use (FAO, 2012). Forest definition in Poland is detailed in the Forest Act of 28 September 1991 (Ustawa o lasach, 1991) as: (1) a homogenous area of at least 0.1 ha, covered with forest vegetation or temporarily without, intended for forest production, representing nature reserve or national park, registered as historic monument; (2) associated with forest management. In this way, Polish forest definition, in general, refers to the first three categories listed above, similarly to the definition accepted by FAO, but using a smaller minimum area. Schepaschenko et al. (2015) noted that the actual global forest map consistent with forest statistics from FAO is still not available.

Considering methods of forest mapping, two approaches seem to be the most popular: remote sensing and land surveys. Contemporary forest cover and forest cover changes have been increasingly mapped using remote sensing, due to the growing frequency and consistently improving temporal and spatial coverage and resolution of satellite data since the 1960s (CORONA mission; McDonald et al., 1995) or the 1970s (Landsat mission, Townshend et al., 2012). A recent breakthrough was a uniform global forest cover change map by Hansen et al. (2013), covering period of 2000-2012, and currently updated till 2018, based on available Landsat data with spatial resolution of $30 \mathrm{~m}$. More recent technologies, such as LiDAR and satellite microwave imagery, allow detailed forest mapping and provide information on three dimensional vegetation structure (Brolly, Woodhouse, 2012; Hyyppä et al., 2012). However, remote sensing perspective, regardless of the data used, is exclusively that of forest being a certain land cover type, and omitting the land use component of forest definitions. With remotely sensed data, all tree covered areas are classified as forest, even when formally they are not, such as cemeteries and urban greenery. Contrary, treeless areas under forest use are excluded from the forest category. In fact, even the presence of dense vegetation may be wrongly interpreted as forest. For instance, Tropek et al. (2014) indicated that the approach of Hansen et al. (2013) does not allow to effectively distinguish between forests and various agricultural plantations.

The other approach to map forests are land surveys. Contrary to the remote sensing methods, they provide detailed knowledge on land use and land cover, yet are 


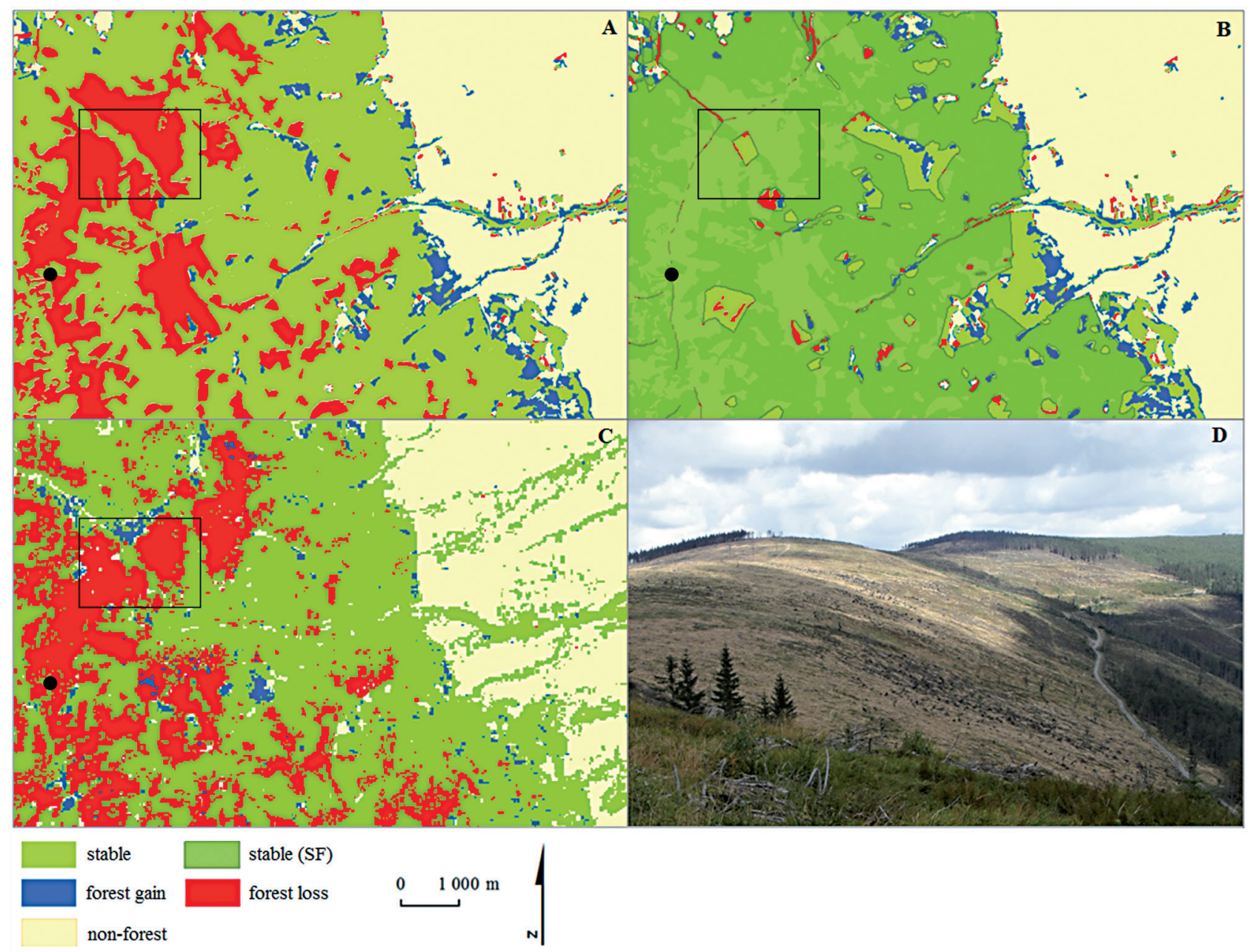

Fig. 1. Forest cover change in the western part of the Silesian Beskid. A - topographic map data (1970s) vs the Polish national topographic database based on aerial photo interpretation (2013); B - topographic map data (1970s) vs the Polish national topographic database based on aerial photo interpretation, combined with SF information on forest use; $\mathrm{C}$ - forest cover changes between 1980s and 2010s, based on processed Landsat time series (Hansen et al., 2013); D - terrestrial imagery of area, 2014, presenting roughly an area indicated with the rectangle. A black dot denotes the location from where the photo was taken. In A and C, degraded spruce forests where trees were removed (as clearly visible in D) are considered the forest loss, in B, no change is mapped as the area of degraded forests is still legally forest and under forest use. C shows also forest gain in areas degraded before 2000 and later reforested - these areas in B are shown as stable forests

Rys. 1. Zmiany powierzchni lasów w zachodniej części Beskidu Śląskiego. A - porównanie map topograficznych z lat 70. XX w. z danymi topograficznymi z 2013 r., uzyskanymi na podstawie analizy zdjęć lotniczych; B - porównanie map topograficznych z lat 70. XX w. z danymi topograficznymi z 2013 r., uzyskanymi na podstawie analizy zdjęć lotniczych, połączonymi z danymi Lasów Państwowych; C - zmiany powierzchni lasów od lat 80. XX w. do drugiej dekady XXI w., na podstawie danych Landsat (Hansen i in. 2013); D - fotografia naziemna z 2014 r., prezentująca obszar zaznaczony prostokątem. Czarne kółko oznacza miejsce wykonania zdjęcia. Rys. A i C ukazują obszary zdegradowanych lasów jako obszary wylesione, natomiast na rys. B obszary te nie są ukazane jako zmiany, ponieważ są ciągle użytkowane jako lasy. Rys. C pokazuje też obszary, na których nastąpił przyrost powierzchni lasów na obszarze zdegradowanym przed 2000 r., a następnie zalesionym - te obszary na rys. B są wykazane jako obszary stabilne 
limited to a specific area and globally inconsistent. Besides, the traditional methods of making a forestinventory are time-consuming and costly. In Poland, the SF forest maps are compiled and updated in land surveys in a 10year cycle, providing detailed spatial data on forest extent stored in the forest digital map (LMN) and various attributes stored in the SF spatial information system (SILP; Zarządzenie, 2012). Information on other forests may be derived from the real estate cadaster database (Ewidencja Gruntów i Budynków, EGiB), which is a parcel-level uniform collection of data on land, buildings and premises, as well as their owners, for the entire country (Rozporządzenie, 2013). The database gathers reports of land owners on formal land use and land cover conversions (including forests) that are later aggregated to administrative units (communes, or NUTS $^{1}-5$ level units) and made available in statistical information systems. Land use and land cover information (including forests) at the parcel level is also stored in the Land Parcel Identification System (LPIS), managed by the Agency for Restructuring and Modernization of Agriculture (ARMA) (Instrukcja..., 2013).

The adoption of a specific forest definition determines selection of various forest mapping methods, and consequently, leads to inconsistencies among forest cover products. This, in turn, affects forest cover change analysis over particular time periods that may show non-existing gains, losses and net changes of forest area. This is in particular evident if forest cover change maps based on remote sensing are compared to maps taking into account land management and land use aspects (Fig. 1).

\section{Materials}

\subsection{Study Area}

We studied the Polish Carpathians, which comprise a north-western part of the Carpathian mountain range, located in the Central Europe. On one hand, the area has experienced a gradual forest cover increase since at least 150 years due to the decline of agriculture, land abandonment and secondary forest succession or afforestation (Kozak, 2010; Musiał, 2011; Kolecka et al., 2017). On the other hand, spruce forests in the Polish Carpathians show severe symptoms of decline leading

\footnotetext{
1 The NUTS classification (Nomenclature of territorial units for statistics) is a hierarchical division system of the EU territory.
}

to large-scale forest degradation resulting in temporarily treeless landscapes, especially in their western part (Main-Knorn et al., 2009).

\subsection{Data}

To compile the contemporary forest map we used a range of up-to-date spatial datasets (Table 1), divided into three categories. BDOT10k, SILP and LMN, and Topo70 data were considered as basic source data to provide contemporary spatial extent of forests in the Polish Carpathians. LPIS and BDL data were used as reference data in order to assess the quality of the final forest map. Contemporary aerial and satellite imagery (ORTHO) and BDoL provided supplementary information about forests, land cover and spatial context.

\section{BDOT10k}

BDOT10k is a national topographic database for the entire area of Poland. The accuracy of BDOT10k corresponds to map scale 1:10,000. The data are divided into nine thematic categories, including land cover and land use. The wall-to-wall land cover data were collected by manual interpretation of orthophotomaps with $1 \mathrm{~m}$ spatial resolution. Resulting land cover categories describe physically homogeneous, coherent and non-overlapping patches of land. For some areas, ancillary information about land use of functionally homogeneous areas, so-called land use complexes, is provided. Categories of land use complexes include for instance groups of buildings and constructions, facilities and communication areas having a common name and common ownership or management. BDOT10k adopts a land cover-oriented forest definition (Rozporządzenie, 2011). For instance, completely degraded forests, though still under forest use, were excluded from the forest area. Most parks and cemeteries were counted as forest as well.

\section{SILP and LMN}

SILP covers about $50 \%$ of forests in the Polish Carpathians being the SF property, and stores attributes of each forest stand that is related to the forest parcel geometry represented in a digital forest map (LMN). The attributes include for instance tree species, age, structure and tree metrics. The accuracy of LMN corresponds to maps in 1:5,000 scale. To map SF forests, the Polish legal definition of forests has been adopted, 
Table 1. The characteristics of available datasets

Tabela 1. Charakterystyka wykorzystanych danych

\begin{tabular}{|c|c|c|c|c|c|}
\hline & Dataset / database & Feature / layer & $\begin{array}{c}\text { Forest } \\
\text { definition }\end{array}$ & Timeliness & $\begin{array}{l}\% \text { of forest area } \\
\text { covered / mapped } \\
\text { in the Polish } \\
\text { Carpathians }\end{array}$ \\
\hline \multirow{3}{*}{ 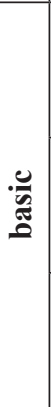 } & $\begin{array}{l}\text { BDOT10k } \\
\text { the National Database of Topographic } \\
\text { Objects 1:10,000 }\end{array}$ & $\begin{array}{l}\text { vector boundaries } \\
\text { forest areas and areas } \\
\text { covered with trees }\end{array}$ & land cover & $2012-2013$ & $100 \%$ \\
\hline & $\begin{array}{l}\text { SILP and LMN } \\
\text { SF IT system including a digital forest } \\
\text { map (LMN) 1:5,000 }\end{array}$ & $\begin{array}{l}\text { vector boundaries } \\
\text { of forest units and } \\
\text { attribute inventory data }\end{array}$ & land use & 2014 & $\sim 50 \%$ \\
\hline & $\begin{array}{l}\text { Topo70 } \\
\text { The Polish Topographical Map } \\
\text { 1:25,000 }\end{array}$ & $\begin{array}{l}\text { forest raster mask } \\
\text { received through semi- } \\
\text { automatic extraction }\end{array}$ & $\begin{array}{l}\text { land use } \backslash \\
\text { land cover }\end{array}$ & $1975-1983$ & $100 \%$ \\
\hline \multirow{2}{*}{ 遶 } & $\begin{array}{l}\text { LPIS } \\
\text { Land Parcel Identification System: } \\
\text { GIS data managed by Agency for } \\
\text { Restructuring and Modernization of } \\
\text { Agriculture (ARMA), 1:2,000-1:5,000 }\end{array}$ & $\begin{array}{l}\text { vector boundaries } \\
\text { of land parcels and } \\
\text { attribute data? }\end{array}$ & land use & 2014 & $\sim 90 \%$ \\
\hline & $\begin{array}{l}\text { BDL } \\
\text { Local Data Bank. Tabular data from } \\
1995 \text { aggregated to communes }\end{array}$ & $\begin{array}{l}\text { land use and land cov- } \\
\text { er data aggregated at } \\
\text { NUTS-5 level }\end{array}$ & land use & 2013 & - \\
\hline \multirow{3}{*}{ 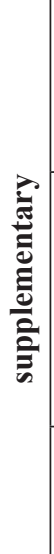 } & $\begin{array}{l}\text { BDoL } \\
\text { Forest Data Bank GIS data, 1:5,000 }\end{array}$ & $\begin{array}{l}\text { vector boundaries } \\
\text { of forest units }\end{array}$ & land use & $\begin{array}{l}\text { mostly as in } \\
\text { SILP\&LMN, } \\
\text { partially un- } \\
\text { known }\end{array}$ & $\sim 70 \%$ \\
\hline & $\begin{array}{l}\text { Global Forest Map (GFM) } \\
\text { Landsat-based forest maps with spatial } \\
\text { resolution of } 30 \mathrm{~m} \text { : } \\
\text { - Tree canopy cover for year } 2000 \\
\text { - Global forest cover gain } 2000-2012 \\
\text { - Year of gross forest cover loss event }\end{array}$ & $\begin{array}{l}\text { raster masks received } \\
\text { from Landsat image } \\
\text { classification }\end{array}$ & land cover & $2000-2012$ & $100 \%$ \\
\hline & $\begin{array}{l}\text { ORTHO } \\
\text { High resolution aerial and satellite } \\
\text { imagery }\end{array}$ & $\begin{array}{l}\text { forest and land cover } \\
\text { visual interpretation }\end{array}$ & land cover & $2009-2015$ & $100 \%$ \\
\hline
\end{tabular}

hence SILP and LMN data refer to land use aspects of forest definition. Forest parcels may therefore include temporarily unstocked areas.

\section{Tоро 70}

Topo 70, the Polish Topographical Map in 1:25,000 scale, was created between $1975-1983$ by the Head Office of Geodesy and Cartography (GUGiK) for the entire area of Poland. Minimum mapping unit was defined as $10 \mathrm{~mm}^{2}$ in map scale, that is 0.625 ha (Instrukcja..., 1980). Topo 70 forests were mapped using concurrent legal forest definition adopting both land use and land cover aspects. Therefore windbreaks or clearings were included in the forest category. Forest cover layer from Topo 70 was obtained in the process of semi-automatic extraction and corrected manually (Ostafin et al., 2017).

\section{LPIS}

A nation-wide database of agricultural parcels (LPIS) has been produced by ARMA using maps, aerial or satellite imagery, land registry documents and other cartographic data. The database is continuously updated by 
means of on-site inspections. LPIS is used to control the system of direct agricultural payments of the European Union Common Agricultural Policy (CAP). Though forest parcels are excluded from payments, they are still stored in the database (separately from wooded areas). LPIS uses the legal Polish definition of forest and reflects the land use aspects of forest definition. As of 2015 , LPIS comprised approximately $80 \%$ of forests in the Polish Carpathians.

\section{$B D L$}

$\mathrm{BDL}$ is the largest database of the economic, social and environmental data in Poland covering the entire country at various spatial aggregation levels. It publishes up-to-date tabular information on forest cover in Poland according to the Polish forest definition. In this way, the total forest area is a sum of forest area and areas related to forest management, similarly as in SILP\&LMN database, including, however, also forests outside SF property. In the study we used BDL forest data of 2013, aggregated at the lowest spatial level (NUTS-5 or commune).

\section{$B D o L$}

BDoL contains and makes available publicly SF data. Some additional information on forests outside SF property retrieved from Forest Management Plans are also stored in the database and made available, yet the coverage is not complete, and many forest areas are missing. For the study area, data extent was wider than that of SILP\&LMN, reaching approximately $75 \%$ of the total forest area, yet metadata for forested areas outside SF property were incomplete or missing.

\section{High resolution aerial and satellite imagery, ORTHO}

Orthorectified aerial or satellite images with the spatial resolution ranging from 1.0 to $0.1 \mathrm{~m}$ were accessed via Web Map Services (WMS) of the national geoportal (www.geoportal.gov.pl). Aerial images were acquired between 2009 and 2015 by the State Geodetic and Cartographic Register (PZGiK), for the entire area of the Polish Carpathians.

\section{METHODS}

\subsection{Forest map}

We developed a set of rules integrating various land cover and land use data to receive the best possible forest layer for 2013. The baseline data were the BDOT10k forest layer features, sequentially updated using another datasets (SILP and LMN, Topo70), provided that specific conditions were met (Fig. 3). Supplementary data were used to control the processing results.

\section{Stage I: forest area extraction from the BDOT10k data}

In the initial step, we extracted forests from BDOT10k land cover layer to produce a preliminary forest layer, referred to as FOREST_0. As in BDOT10k, forest belongs to the class forest areas and wooded land, which contains 3 types of vegetation: forest, copse and wooded land, we first included fully forest and copse types into FOREST_0. As for the wooded land category, a visual inspection showed that the wooded land category frequently did not represent forested area, and therefore the category required additional verification. For this purpose we used land use information from the BDOT10k, Topo70, ORTHO and BDoL. First, wooded land patches overlapping land use types related to non-agricultural and non-forest activities (e.g., educational, industrial, sacral) were excluded from the FOREST_0 layer. Additional visual interpretation was applied to the areas of residential land use using ORTHO and BDoL data to confirm the correctness of the exclusion. The remaining wooded land patches were

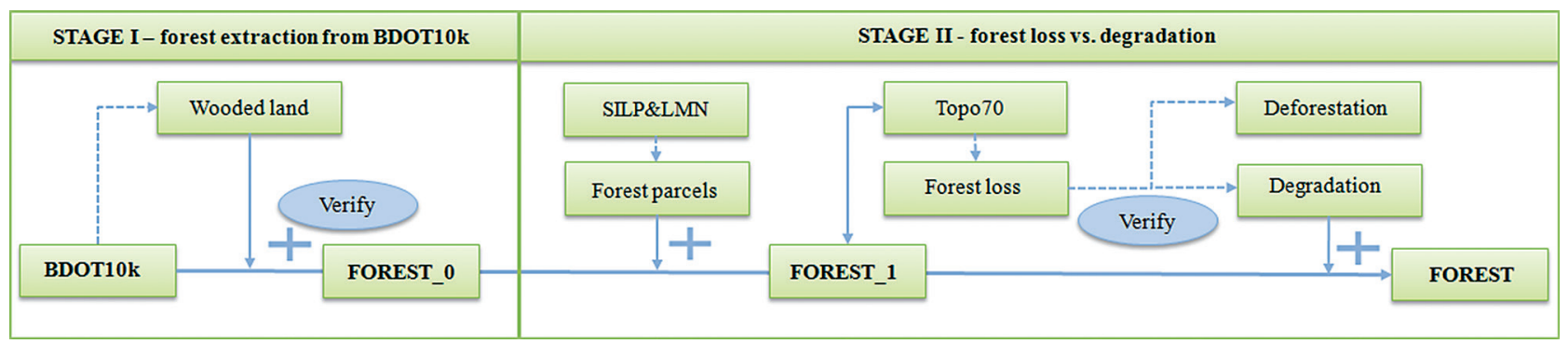

Fig. 2. General workflow towards the final forest map

Rys. 2. Schemat postępowania prowadzący do uzyskania końcowej mapy lasów 
included to FOREST_0 layer in three cases: (1) they were forests in the 1970s (verified based on Topo70), (2) they had an area greater than 5 ha, or (3) they shared boundary with forest class in BDOT10k. The latter criterion was additionally tested through visual interpretation of ORTHO and BDoL data. Finally, following the legal Polish forest definition, we removed forest patches with an area less than 0.1 ha, receiving the final FOREST_0 layer (Fig. 3).

\section{Stage II: discriminating areas of forest degradation}

The most important problem encountered at the second stage of the analysis was how to efficiently map areas of degraded forests. The degraded forests are temporarily unstocked due to natural or anthropogenic causes and expected to revert to forest (Lund, 1999). In BDOT10k the degraded forests were frequently included into grasslands instead of forests, contrary to the Polish legal forest definition. Therefore, the forest layer derived at the first stage solely from the BDOT10k data (FOREST_0) overlaid on earlier forest data (e.g., Topo 70) showed many areas with forest losses (Fig. 1). However, only some of these losses represented a real forest loss (deforestation) understood as removal of a forest as a consequence of land use change from forest to other land (Lund, 1999), while most represented forest degradation.
To tackle the problem of degraded forests we extracted first all parcels of forest land use based on SILP\&LMN data, for the areas within SF property. They were then overlaid on FOREST_0, appending to the forest layer all degraded forests within the SF property. A resulting layer was referred to as FOREST_1. For the areas outside the SF property, no information comparable to SILP\&LMN exists in a coherent and digitally accessible format. Therefore in the next step we decided to refer to forest cover information extracted from Topo 70 and our expert knowledge on forest cover change trends in the last 40 years. Based on FOREST_1 and Topo70, we extracted all areas of forest loss between 1970s and 2013 outside SF property. Then we applied to all patches the following two rules:

(1) if BDOT10k land cover information for a forest loss patch was grassland or shrubland and there was no land use change according to BDOTK10k land use classes, the loss patch was labelled as degraded forest and included in the final forest layer (FOREST);

(2) if BDOT10k land use types were present (e.g., residential, recreational, infrastructural), a forest loss patch was regarded as actual deforestation and was not included in the forest layer.

Ambiguous cases were verified visually with high resolution imagery, for all forest loss patches larger than 5 ha (approximately $3 / 4$ of all forest loss patches). After

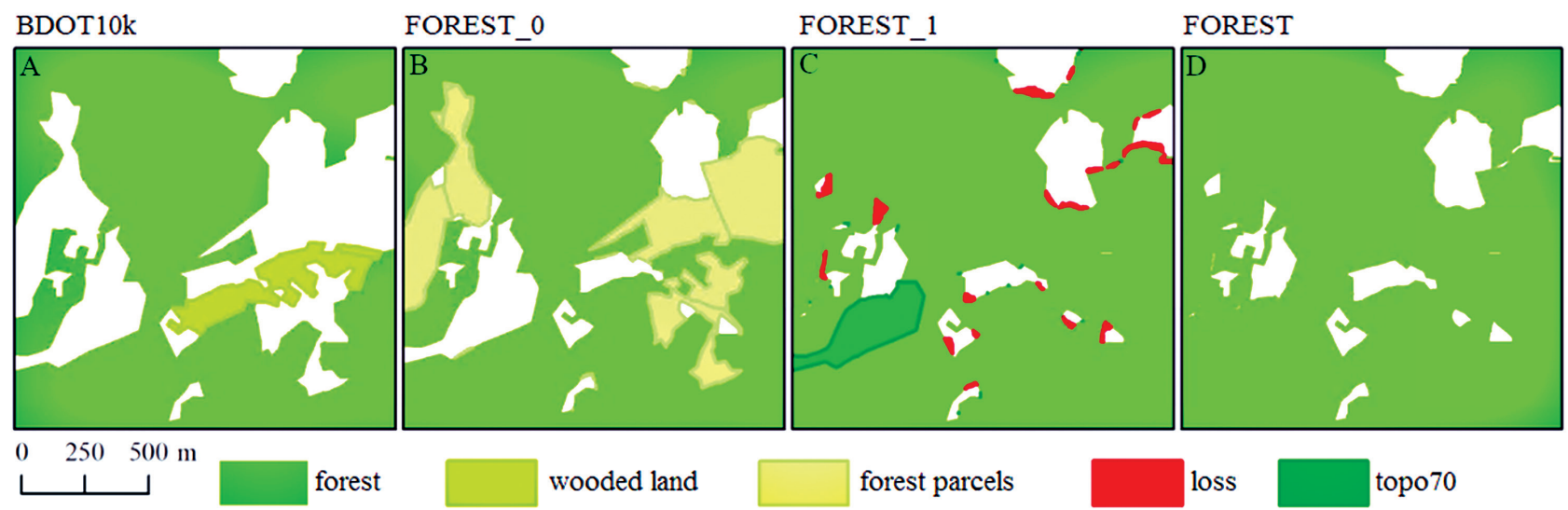

Fig. 3. Outputs of subsequent stages of the proposed methodology. A - BDOT10k, forest mask made up of forest and copse classes of BDOT10k, and wooded land; B - FOREST_0; C-FOREST_1 (FOREST_0 and SF parcels); forest losses (red polygons) are identified through comparison of Topo70 and FOREST_1; D - final FOREST mask received through adding verified forest losses to FOREST_1

Rys. 3. Wyniki kolejnych etapów przyjętego toku postępowania. A - BDOT10k, mapa lasów utworzona z klas BDOT10K "las" i ,zagajnik” oraz „zadrzewienie”; B - FOREST_0; C - FOREST_1 (FOREST_0 oraz własność Lasów Państwowych); D - końcowa mapa FOREST uzyskana dzięki manualnej weryfikacji ubytków lasu w warstwie FOREST_1 
labelling all forest loss patches with either "forest" or "non-forest", and updating FOREST_1 mask we received the final contemporary forest layer, referred to as FOREST (Fig. 3).

\subsection{Assessing quality of the forest map with reference data}

We assessed the resulting final forest cover layer (FOREST layer) using three various approaches and independent forest cover data available for the entire study area. First, we compared the FOREST layer to forest cover layers received from the LPIS data using a binary map overlay, in this way receiving amount of forest mapped consistently and forest mapping inconsistencies in these two different polygon layers. Next, for all communes completely contained in the Carpathian region we compared per commune forest proportion based on the FOREST layer with forest proportion estimates according to LPIS and BDL data sources, receiving communal-level maps of forest cover discrepancies between various sources. Finally, we identified communes with the highest discrepancies, and for these communes, manual interpretation based on supplementary data was applied to check and explain causes of highest discrepancies.

\section{RESULTS}

The methodology proposed in this study started from the BDOT10k data and subsequently appended forest cover data from various sources to the initial on forest and copse classes from BDOT10k (Fig. 3). Forest cover in the Polish Carpathians based only on forest and copse classes from BDOT10k was $48.1 \%$. From the BDOT10k class wooded land, $95.2 \mathrm{~km}^{2}(70.7 \%$ of wooded land) were reclassified to forest and included in the preliminary forest layer-FOREST_0, increasing the forest proportion to $48.6 \%$. Based on SILP\&LMN data, $127.6 \mathrm{~km}^{2}$ of forest were added to the FOREST_0 mask, thus FOREST_1 mask covered $49.3 \%$ of the study area. In the last step, $17.9 \mathrm{~km}^{2}$ of forest losses between 1970 and 2013 were identified as forest degradation and included to the final forest layer (FOREST). The area of forest in the final forest mask was 8943.9 $\mathrm{km}^{2}$, constituting $49.4 \%$ of the study area (Fig. 4). The final forest layer is not published here, yet the data are available at request from the Institute of Geography and

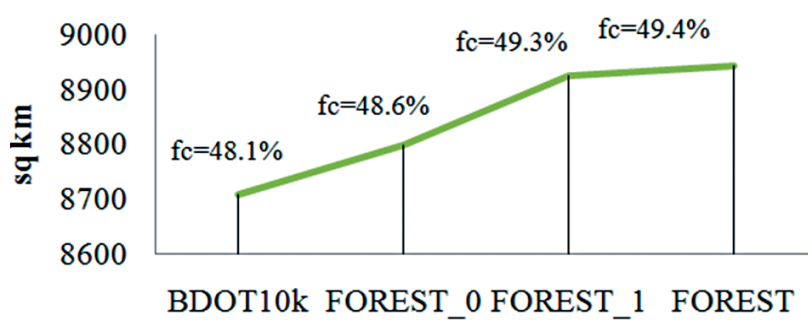

Fig. 4. Forest cover (fc) estimates for all processing stages Rys. 4. Szacunki lesistości na kolejnych etapach przyjętego toku postępowania

Spatial Management, Jagiellonian University (Kozak, Kaim, 2016).

Forest cover in the Polish Carpathians obtained from LPIS and BDL was $45.2 \%$ and $43.2 \%$, respectively, which is in both cases lower than the value calculated from FOREST. Forest polygons in our final forest mask showed a very good agreement with the LPIS spatial forest data $(97.8 \%)$. At the commune level, forest cover values calculated from the reference data (LPIS and BDL) were highly correlated with values obtained from the final forest masks $\left(\mathrm{R}^{2}>0.90\right)$, yet the reference commune-level forest cover rates were systematically below the estimates of our product (Fig. 5).

As compared to LPIS data, our forest mask indicated higher forest cover for most of the area, especially in the north-western and eastern communes, and significantly lower in one commune in the southern part of the study area. Maximum difference was noted in Stryszawa (23.9 percent points [pp]) and the minimum difference in Kościelisko ( $-10.5 \mathrm{pp}) .3$ communes showed differences in between -1 and $1 \mathrm{pp}$. As compared to the BDL data, our forest mask showed forest cover values higher by $6 \mathrm{pp}$ or more in most of the analysed communes. The maximum difference was noted in Domaradz (18.5 pp) and the minimum difference in Zakopane ( -13.5 pp). 5 communes showed differences in between -1 and $1 \mathrm{pp}$.

\section{DISCUSSION}

In this study we produced a map of contemporary forests in the Polish Carpathians, a region with a significant knowledge gaps due to a large share of inadequately mapped forests outside the SF property. Our map showed that other independent official sources, LPIS 


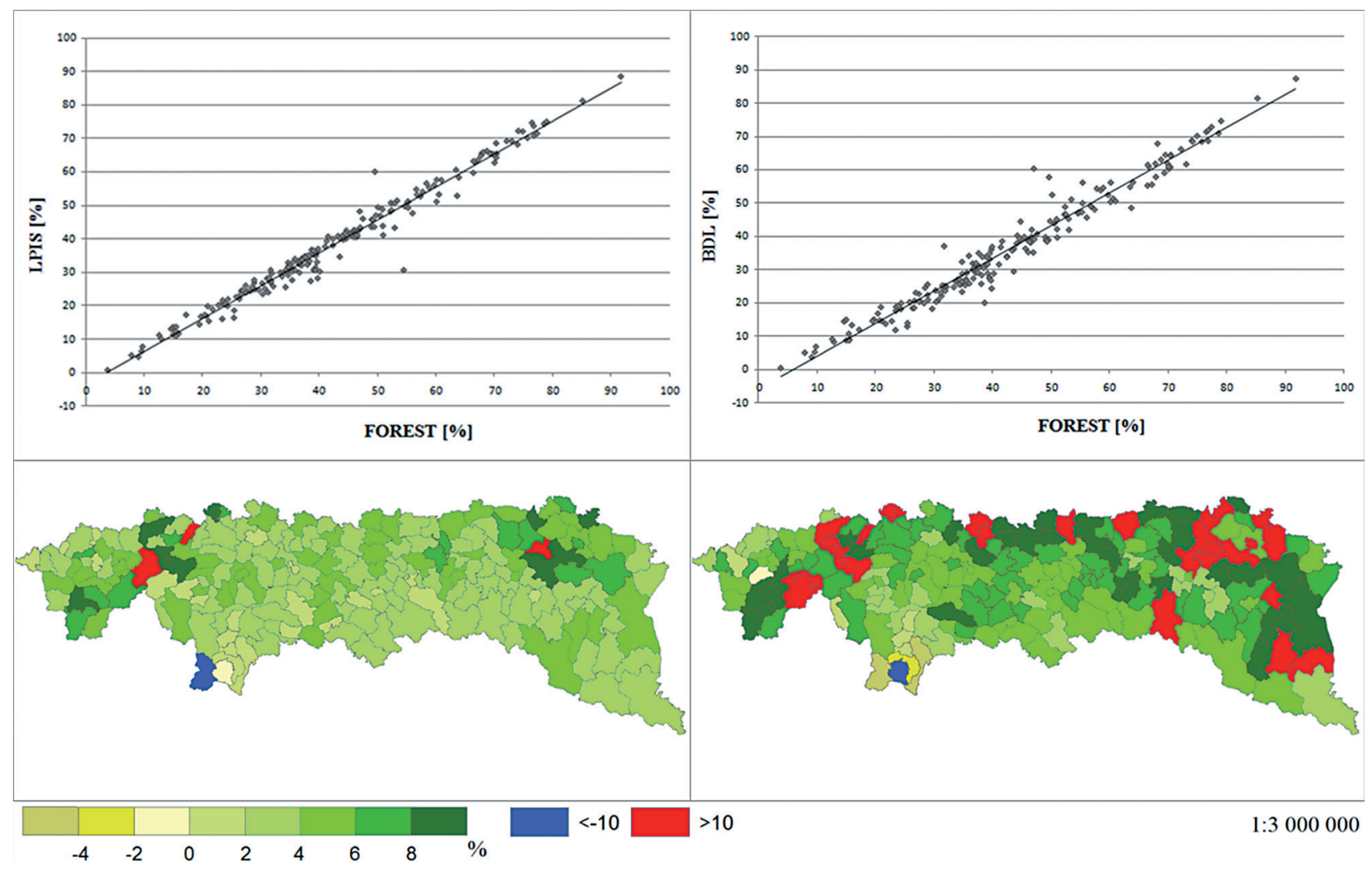

Fig. 5. Forest cover from FOREST vs reference data

Rys. 5. Porównanie lesistości z mapy FOREST z danymi referencyjnymi

and BDL, may underestimate forest cover in the region by $4.2 \mathrm{pp}$ and $6.2 \mathrm{pp}$, respectively. FOREST and LPIS forest cover estimates for most communes were substantially coherent, and the differences resulted mainly from data gaps in LPIS data coverage, e.g., half of the forest area in the Stryszawa commune (were the maximum difference was noted) was not mapped in the LPIS data. In some communes, however, we identified thematic inconsistencies between the final forest mask, SILP\&LMN data and LPIS, indicating LPIS errors, or high mountain areas (Tatra Mts.), where rocks, grasslands and mountain pine were classified as forest in LPIS, in this way overestimating forest cover (the case of the Kościelisko commune).

As BDL data are only tabular data it was not possible to verify the exact causes of high underestimation of forest cover in BDL as compared to FOREST. This discrepancy is clearly an effect of delays in recording land use and land cover changes in BDL data, in particular secondary forest succession. Only in one case, Zakopane, forest cover in BDL was significantly higher than that calculated from FOREST, the reason here may be likely related to including forested recreation areas to the forest class in BDL. Interestingly, we also noted discrepancy between LPIS and BDL forest cover, confirming important inconsistencies in the official Polish data sources on land use and land cover.

The final forest map does not possess a significant drawback of BDOT10k data, that is omission of degraded forests in the forest class. While it is coherent with two other data sources with a complete coverage, it is superior to BDL data, due to the inclusion of recent secondary forest succession in BDOT10k data, not reported up-to-date in BDL data. Contrary to LPIS, it does not have any data gaps. However, inclusion of the recent secondary forest succession into the final forest map may also lead to overestimation of the forest area as some of abandoned and overgrown areas may in fact never be turned into forests (e.g., abandoned agricultural land with secondary forest succession may be also converted to residential area before receiving the legal status of forests; Grădinaru et al., 2019). 
Our study shows that some of the discrepancies noted between various data sets may be related to problems with data updates. This is especially a case of data sets relying on formal reporting that does not take advantage of much quicker data acquisition through remote sensing. In our final forest map, similarly as the Polish legal forest definition, we were able to include both land use and land cover aspects of forest definition through the integration of various sources. Besides situations completely clear from the viewpoint of forest classification (e.g., areas covered by trees and managed as forests), the land use aspect was related to the inclusion of all degraded forest areas that are managed as forests in the forest category. Importantly, remote sensing based forest data exclude these areas from forests (e.g., Hansen et al., 2013). The land cover aspect, on the other hand, was reflected in the inclusion of secondary forest succession areas, with mature trees, that at the moment do not need to be formally registered as forests. As the recent LiDAR-based studies show (Kolecka et al., 2017), this process is of high areal significance in the studied region and may be considered as the initial stage of the future forest cover increase. If secondary forest succession areas were not included in forests, that would decrease the value of any long-term reconstructions of land use and landscape dynamics, and underestimate the carbon balance. In this way, our study shows that forest concepts and definitions influence how we assess and interpret forest, and its changes over time within a geographic region (Chazdon et al., 2016).

Hościło et al. (2016) suggested a slightly modified approach to map forests in Poland, reflecting a similar to ours concern that an accurate estimate of forest cover in Poland is unknown. They study used both BDOT10k and SILP and LMN data, alongside with high resolution satellite data. While their findings related to shortcomings of the official statistics in Poland and underestimation of forest cover were consistent with ours, we find their approach less useful in the area with a high share of forests outside the SF property, and fine-grained forest-agricultural mosaic, typical for the Carpathians. One reason is that to process the entire territory of Poland (10 times more than the Polish Carpathians) Hościło et al. (2016) had to rely on automatic image classification procedures while we were able to use also a visual interpretation. Another reason was that we used the information on the past forest cover (1970s) which, combined with an expert knowledge and visual image interpretation, allowed to improve the final forest mask in areas where a simplistic map overlay signalized forest loss in the period 1970-2013. Our approach based on using the past forest cover information thus benefitted from the process similar to map back- or updating, which are commonly used in land use and land cover change reconstructions (Kaim et al., 2016).

\section{CONCLUSIONS}

Current digital spatial databases give various possibilities to combine a huge number of thematic layers and select any object from each layer, thus providing a lot of editing and analytical capabilities, as well as new ways to visualize the spatial data (Luc et al., 2015). Mapping technologies are increasingly based on building complex actual databases, with data collection process reduced to the quick and efficient automatic extraction of information from remotely sensed data. Therefore, even rapid changes in land cover, e.g., such as those occurring in the past 25 years in the Carpathian region, may be easily recorded with high temporal frequency, allowing to build accurate long-lived databases, while the static land use perspective - extremely important in terms of the long term trends of forest cover change loses its significance. In our study, this was noticeable in the case of the BDOT10k database which represents the current land cover, unlike to previous editions of topographic maps in Poland, representing the land use perspective. The problem with inconsistencies in the forest cover data for the Polish Carpathians we found in our study reflects therefore, quite likely, a generic problem with integrating topographic data collected according to two different paradigms related to temporal properties of topographic objects. In the past, map making was a long and difficult process, therefore maps were usually presenting permanent and stable topographic objects being more focused on the use of the land than on land cover. Currently, mapping relies on remote sensing and may easily, with a very high temporal resolution, reflect a quickly changing land dynamics. As one of the goals driving this research were long-term reconstructions of forest cover trajectories, such a paradigm shift undermined their consistency, and demanded a careful harmonization of various contemporary data to reduce related uncertainty of the reconstruction of forest cover trends. 
Our work reveals that the abundance of spatial data and variety of data acquisition methods may, on one hand, help to update existing spatial data sets, producing likely more accurate and reliable results. On the other hand, however, various available data on forests in Poland lead to ambiguities and difficulties to accurately provide even the most basic figures, like forest cover over a certain area. For the Polish Carpathians, our final estimate was $49,4 \%$, while at the other extreme the value derived from the BDL data was $43,2 \%$. Such a discrepancy is a major obstacle in any study requiring an accurate forest cover estimate and calls for an effort to harmonize existing spatial data with respect to the legal forest definition accepted in Poland, including also private forests. A desired outcome of such an effort is a national reference forest cover layer, which may reduce the work load of various agencies producing partially overlapping and redundant forest cover data.

\section{ACKNOWLEDGMENTS}

Research carried out within the FORECOM project (Forest cover changes in mountainous regions - drivers, trajectories and implications, PSRP-008/2010), supported by a grant from Switzerland through the Swiss contribution to the enlarged European Union.

\section{REFERENCES}

Andersson K., Evans T. P., \& Richards K. R. (2009). National forest carbon inventories: Policy needs and assessment capacity. Climatic Change, 93(1-2), 69-101.

Bonan G. B. (2008). Forests and climate change: forcings, feedbacks, and the climate benefits of forests. Science, 320(5882), 1444-1449.

Brolly M., \& Woodhouse I. H. (2012). A "Matchstick Model" of microwave backscatter from a forest. Ecological Modelling, 237-238, 74-87.

Chazdon R. L. et al. (2016). When is a forest a forest? Forest concepts and definitions in the era of forest and landscape restoration, Ambio, 45(5), pp. 538-550. doi: 10.1007/s13280016-0772-y.

Comber A. (2008). The separation of land cover from land use using data primitives. Journal of Land Use Science, 4(4), 215-229.

FAO (2012). Forest Resources Assessment Working Paper FRA 2015: Terms and Definitions.

Fisher P., Comber A., \& Wadsworth R. (2005). Land use and Land cover: Contradiction or Complement. Re-Presenting GIS, (JANUARY).

Ustawa o lasach (1991). Dz. U. 1991 No. 101, item. 444, Article 3 .
Grădinaru S. R., Kienast F., Psomas A. (2019). Using multi-seasonal Landsat imagery for rapid identification of abandoned land in areas affected by urban sprawl. Ecological indicators, 96, 79-86.

Gschwantner T., Schadauer K., Vidal C., et al. (2009). Common tree definitions for national forest inventories in Europe. Silva Fennica 43(2), 303-321.

Hansen M. C., Potapov P. V, Moore R., Hancher M., Turubanova S., Tyukavina A., Townshend J. R. G. (2013). High-resolution global maps of 21 st-century forest cover change. Science, 342, 850-3.

Hościło A., Mirończuk A., Lewandowska A. (2016). Określenie rzeczywistej powierzchni lasów w Polsce na podstawie dostępnych danych przestrzennych. Sylwan 160, 627-634.

Hyyppä J., Hyyppä H., Vastaranta M., Holopainen M., Kukko A., Alho P. (2012). Advances in forest inventory using airborne laser scanning. Remote Sensing, 4(5), 1190-1207.

Instrukcja realizacji kontroli w zakresie kwalifikowalności powierzchni, 2013, Warszawa.

Instrukcja Techniczna K-2 - Mapy topograficzne do celów gospodarczych, 1980. Wyd. 2 Warszawa.

Jabłoński M. (2015). Definicja lasu w ujęciu krajowym i międzynarodowym oraz jej znaczenie dla wielkości i zmian powierzchni lasów w Polsce. Sylwan 159(6), 469-482.

Kaim D., Kozak J., Ostafin K., Dobosz M., Ostapowicz K., Kolecka N., \& Gimmi U. (2014). Uncertainty in historical land-use reconstructions with topographic maps. Quaestiones Geographicae, 33(3), 55-63.

Kaim D., Kozak J., Kolecka N., Ziółkowska E., Ostafin K., Ostapowicz K., Gimmi U., Munteanu C., Radeloff V.C. (2016). Broad scale forest cover reconstruction from historical topographic maps, Applied Geography, 67, 39-48.

Keenan R. J., Reams G. A., Achard F., de Freitas J. V., Grainger A., \& Lindquist E. (2015). Dynamics of global forest area: Results from the FAO Global Forest Resources Assessment 2015. Forest Ecology and Management, 352, 9-20.

Kolecka N., Kozak J., Kaim D., Dobosz M., Ostafin K., Ostapowicz K., Wężyk, P., Price B. (2017). Understanding farmland abandonment in the Polish Carpathians. Applied Geography, $88,62-72$.

Kozak J. (2010). Forest Cover Changes and Their Drivers in the Polish Carpathian Mountains Since 1800. In: Nagendra H., Southworth J., (eds), Reforesting Landscapes. Linking Pattern and Process. Landscape Series 1: 253-273, Springer Verlag.

Kozak J., Kaim D. (eds) (2016). FORECOM: Podręcznik użytkownika, IGiGP UJ, Kraków.

Kunz M., 2006. Standaryzacja danych kartograficznych i teledetekcyjnych do analizy zmian struktury krajobrazu. Roczniki Geomatyki, 6(3), 119-127.

Lesiv M., Moltchanova E., Schepaschenko D., See L., Shvidenko A., Comber A., \& Fritz S. (2016). Comparison of Data Fusion Methods Using Crowdsourced Data in Creating a Hybrid Forest Cover Map. Remote Sensing, 8(3), 261.

Luc M., Kozak J., Ostafin K., Kolecka N., Kaim D., Trzepacz P. (2015). Historia dwóch map (Story of two maps). In: Geo- 
grafia na przestrzeni wieków. Tradycja i wspótczesność, IGiGP UJ, 225-236.

Lund H. G. (1999). A “forest” by any other name. Environmental Science \& Policy, 2, 125-133.

Lund H. G. (2014). What is a forest? Definitions do make a difference: An example from Turkey. Avrasya Terim Dergisi, 2 (1), 1-8.

Main-Knorn M., Hostert P., Kozak J., Kuemmerle T. (2009). How pollution legacies and land use histories shape post-communist forest cover trends in the Western Carpathians. Forest Ecology and Management, 258, 60-70.

McDonald R.A. (1995). Corona: success for space reconnaissance, a look into the Cold War, and a revolution in intelligence. Photogrammetric Engineering \& Remote Sensing, 61 (6, June), 689-720.

Musiał W. (2011). Conditions and assessment of adequacy of supporting agriculture in Polish Carpathian Mountains. Oeconomia, 10 (4), 65-74.

Ostafin K., Iwanowski M., Kozak J., Cacko A., Gimmi U., Kaim D., Psomas A., Ginzler C., Ostapowicz K. (2017). Detection of forest on historical topographic maps based on image processing. Geoscience Data Journal, 4, 29-39.

Raport o stanie lasów w Polsce 2015, Centrum Informacyjne Lasów Państwowych.

Rozporządzenie (2011). Rozporządzenie MSWiA z dnia 17 listopada 2011 r. w sprawie bazy danych obiektów topograficznych oraz bazy danych obiektów ogólnogeograficznych, a także standardowych opracowań kartograficznych. Dziennik Ustaw 2011, nr 279, poz. 1642.

Rozporządzenie (2013). Rozporządzenie Ministra Administracji i Cyfryzacji z dnia 29 listopada 2013 r. zmieniające rozpo- rządzenie w sprawie ewidencji gruntów i budynków, Dziennik Ustaw 2013, poz. 1551.

Sasaki N., \& Putz F. E. (2009). Critical need for new definitions of "forest" and "forest degradation" in global climate change agreements. Conservation Letters, 2(5), 226-232.

Schepaschenko D., See L., Lesiv M., McCallum I., Fritz S., Salk C., ... Ontikov P. (2015). Development of a global hybrid forest mask through the synergy of remote sensing, crowdsourcing and FAO statistics. Remote Sensing of Environment, 162, 208-220. http://doi.org/10.1016/j. rse.2015.02.011.

Szostak M., Wężyk P., Tompalski P. (2014). Aerial Orthophoto and Airborne Laser Scanning as Monitoring Tools for Land Cover Dynamics: A Case Study from the Milicz Forest District (Poland). Pure and Applied Geophysics, 171, 857-866.

Townshend J.R., Masek J.G., Huang C., Vermote E. F., Gao F., Channan S., Wolfe R.E. (2012). Global characterization and monitoring of forest cover using Landsat data: opportunities and challenges. International Journal of Digital Earth, 5(5), 373-397.

Tropek R., Sedláček O., Beck J., Keil P., Musilová Z., Šímová I., Storch D. (2014). Comment on "High-resolution global maps of 21st-century forest cover change". Science, 344 (6187), 981.

Ustawa z dnia 28 września 1991 r. o lasach, Dz.U. 1991 nr 101 poz. 444.

Zarządzenie (2012). Zarządzenie nr 83 z dnia 23 listopada 2012 r. w sprawie korekty Instrukcji Urządzania Lasu stanowiącej załącznik do Zarządzenia nr 55 Dyrektora Generalnego Lasów Państwowych z dnia 21 listopada 2011 r. (ZU 042 $0181 / 2012$ ). 